\title{
THE ISLAMIC PUBLIC SPHERE: MANIFESTATIONS OF ISLAM IN THE CONTEMPORARY INDONESIA
}

\author{
Syaifudin Zuhri \\ UIN Sunan Kalijaga \\ Email: syaifuddinzuhri@yahoo.com
}

\begin{abstract}
Abstrak
Sejak runtubnya singgasana Orde Baru, ruang publik di Indonesia diwamai dengan beragam manifestasi dan corak keberagamaan masyarakat muslim. Artikel akan membabas, pertama, sejarah sosial-politik yang melatarbelakangi labimya "Islamic Public Spbere" dan ragam manifestasi Islam di ruang publik paska Orde Baru. Melalui artikel ini, penulis berargumentasi babwa konteks 'depolitisasi' Orde Baru, situasi dunia Islam paska revolusi Iran tabun 1979, ledakan barga minyak pada dekade 1970 an adalab di antara beberapa faktor yang melabirkan kelas menengab muslim di Indonesia. Labirnya kelas menengah muslim ini kemudian diperkuat dengan semakin berkembanganya tekbnologi informasi yang menyebabkan interaksi global semakin intens. Pada bagian kedua, penulis menggambarkan ragam manifestasi Islam parka Orde Baru, mulai dari yang bernuansa ideologis, politis-radikal, bingga popular.
\end{abstract}

مستخلص

منذ اهيار عرش النظام الجديد، في المجال العام في اندوتيسيا مع ظالال ملونة متنوعة من مظاهره، والطوانف الدينية مسلم .وسوف تناقش المادة، أولا، التارتخ الاجتماعي والسياسي وراء ولادة "المجال الغام الاسلامي" ومختلف مظاهر الإسالام في نظام ما بعد العام الجديد .من خلال هذه المقالة، جادلث بأن سياق "علم تسييس "للنظام الجديل، فإن الوضبع العالم الإسعلامي في مرحلة ما بعد ثورة 19V9 'الإيرانية، وانفجار أسعار النفط في : 198 sكان من بين العديل من العوامل التي ولدت الطبقة المتوبطة من المسلمين في اندونيسيا .وتم كنلك تأكيد ولادة الطبقة الوسطل مسلم من معلومات الرائدة في مجال التكنولوجيا التفاعل العالهي المكثف على نجو 
454 Millab Vol XI, No. 2, Februari 2012

$$
\begin{aligned}
& \text { متزايد .في الجزء الثاني، يصف المؤلف مختلف مظاهر النظام ما بعد جديد الإسلام، بلدءا من } \\
& \text { الفروق الدقيقة في الايديولوجية، حتى الشعبية السياسية والراديكالية،. }
\end{aligned}
$$

Keywords: Orde Baru, Islam Global, Iran Revolution

\section{A. Introduction}

Indonesians have witnessed the religious revival among believers. This religious resurgence has been observed since the 1980 s when religion openly came into the public providing people with religious nuance as an alternative to modern hedcnism and capitalism, in addition to as a political vehicle for protest. However, the mentioned period of religious revival was limited to bourgeoisie class, leaving middle and lower classes struggling with their daily problems, and intellectuals. But, the contemporary situation shows otherwise as the resurgence rapidly expands and reaches people from diverse backgrounds and classes. The economic growth of society and cheap-technological products, mainly imported from China, and the internet make Indonesians easier and more convenient to access information and to attain religious guidance.

This paper is aimed at addressing two important discussions. First, it discusses the driving factors contributing to the creation of Islamic sphere in Indonesia. It argues that the political contexts of the New Order, the intemational situation of the Muslim World after the Iranian revolution, the 1970s oil boom, leading to the rise of Indonesian Muslim middle class, and the acceleration of the media and technology are important factors for the emergence of Islamic sphere in Indonesia. Second, the paper highlights some visible manifestations of Islam in the contemporary Indonesian public sphere. The manifestation includes varieties of public appearances of Islamicness, ranging from the ideological, spiritual, to the economic ones. However, it is not worthy the following manifestations are not deemed as sealed characterisation of Indonesian Islam as spectrums of Islam in contemporary Java, Indonesia at 
large, as Ricklefs mentions, are too complex and mostly confusing. ${ }^{1}$ Therefore, rather than maintained as a comprehensive study on varieties, this study is better perceived as an elementary inquiry on manifestations of Islam in the contemporary Indonesian public sphere.

\section{B. The Emergence of Religious Sphere in Indonesia: the State and Society}

The notion of religious sphere is deduced from the idea of public sphere in the Western context which is, for some scholars, considered as lacking its theoretical significance whether applied in the Muslim world. ${ }^{2}$ Whereas the limited definition of the so-called public sphere in the West implies the receding roles of religion, enclosing the significance of religion to households and private matters, religious sphere supposes otherwise as the latter maintains the significant roles of religion in the public space. ${ }^{3}$ This has been also noted by Casanova who argues the 'deprivatisation' of religion in the modern world takes - the thesis of secularism to the other way around. ${ }^{4}$ Responding to Jürgen Habermas, whose name is closely associated with the idea of the public sphere, Schulze develops the idea of an "Islamic public sphere"-Islamische Öffentlichkeit in German- ${ }^{6}$ which refers to the highly diverse invocations of Islam as ideas and practices that 'ulama, intellectuals, sufi orders, students, politicians and many

1 M.C. Ricklefs, "Religion, Politics, and Social Dynamics in Java: Historical and Contemporary Rhymes", Greg Fealy, Sally White (eds.), Expressing Islam: Religious Life and Politics in Indonesia (Singapore: ISEAS Publishing, 2008), pp. 115-136.

${ }^{2}$ Quintan Wiktorowicz, The Management of Islamic Activism (New York: State University of New York Press, 2001), p. 53.

${ }^{3}$ Armando Salvatore and Dale F. Eickelman, "Preface Public Islam and the Common Good," Armando Salvatore and Dale F. Eickelman (eds.), Islam and the Common Good (Leiden: Brill, 2006); Muhammad Qasim Zaman, The Ulama in Contemporary Islam: Custodian of Change (Princeton: Princeton University Press, 2002) 1994)

4 José Casanova, Public Religions in the Modem World (Chicago: University of Chicago Press,

${ }^{5}$ Craig Calhoun, "Introduction: Habermas and the Public Sphere," in Craig Calhoun (ed.), Habermas and the Public Spbere (Studies in Contemporary German Social Thought) (Cambridge: MIT Press, 1993), pp. 1-48.

${ }^{6}$ Reinhard Schulze, A Modem History of the Islamic World (London: IB Tauris, 2000) 
others make to civic debate and public life. ${ }^{7}$ Of the significant signs for this Islamic sphere are the revival and visible roles of Islam in the public space.

In Indonesia, the emergence of Islamic sphere has been observed since the 1980 s, but what are determinative factors contributing to the emergence of Islamic sphere in Indonesia? Answering this question $I$ argue that the creation of Islamic sphere in Indonesia is closely connected to, following Habermas, structural transformation of the society. ${ }^{8}$ The transformation, ranging from the cultural, social, political to technological advancement, further has accelerated the emergence of the so-called Islamic public sphere. The 1970s oil boom is one of importance factors contributing to this transformation as it generated the growth of macro-economic and subsequently created the Indonesian middle class. The 1970s oil boom provided Indonesia with an export revenue windfall that contributed to sustained high economic growth rates, averaging over $7 \%$ from 1968 to 1981 . Along with this growth, foreign investment flowed into Indonesia, particularly into the rapidly developing export-oriented manufacturing sector, and from 1989 to 1997, the Indonesian economy grew-by an average of over 7\%. ${ }^{9}$ To be precise, Indonesian Muslims started to feel the revenue windfall of the developmentalism project of the state. The level of literacy, improved-level of education and economy started to grow among

${ }^{7}$ Dale F. Eickelman and Armando Salvatore, "Public Islam as an Antidote to Violence?," in Esther E. Gottlieb (ed.), Identity Conflicts: Can Violence be Regulated? (New Jersey: Transaction Publishers, 2007), p. 80-81;

8 The notion of structural transformation refers to the rise of public sphere in the seventeenth- and eighteenth century Europe alongside the rise and transformation of modem nation states as well as on the basis of capitalist economy activity. Habermas discussed the invasion of traditional public sphere, restricted to small elite, by the bourgeoisie -in other words, 'private people come together as a public'. The public develops its own informal institutions, such as coffee-houses and newspapers, which led to the emergence of an arena of debate and encouraged rational and critical thought See, Jürgen Habermas, The Structural Transformation of the Public Spbere (Studies in Contemporary German Social Thougbt) (trans. Thomas Burger) (Cambridge: The MTT Press, 1989); Craig Calhoun, "Introduction: Habermas and the Public Sphere,"; Peter Burke, History and Social Theory, $2^{\text {nd }}$ ed. (Cambridge: Polity, 2005), p. 79.

9 Adam Schwarz, A Nation in Waiting: Indoneria's Search for Stability (Oxford: Westview Press, 2000.), pp. 52-57. 
Indonesians, but along with this economic development, the level of corruption also expanded among the state officials, bureauctats, elites and their families. ${ }^{10}$

The 1979 Iranian revolution is of importance influence in the creation of Islamic public sphere in Indonesia. It led to the intensification of Islamic discussion among university students. The successful Mulla revolution gave a birth to the self-convincing view that Islam is an altemative way of life in the face of Westemisation. ${ }^{11}$ Along with this wave, a number of Shi'i thinker books wete translated into Bahasa Indonesia, walking side-by-side with their Sunni counterparts, such as that of Hassan al-Banna, Sayyid Qutb and else. In addition to the foregoing external influence, the state restrictive policy known as the Normalization of Campus Life/Coordinatory Body for Campuses (Normalisasi Kebidupan Kampus/Badan Koordinasi Kampus, NKK/BKK) in 1978 that prohibited university students from playing an active part in politics further initiated to the rise of so-called 'campus Islam' among university students by which, among other things, the slogan 'Islam is the solution' began to steadily expand. These young intellectuals, later well-known as tarbiyab activists, ${ }^{12}$ are very critical to the government as the letter was deemed as showing antagonistic attitudes to Islam. Furthermore, they insisted to return to the Qur'an and the Sunna as the foundational sources of the state and were against the state ideology, Pancasila.

In addition, the transformation is also significantly influenced by the changing attitudes of the New Order government towards Islam. Being traumatised by the danger left-wing prevalent among abangan ${ }^{13}$ and other locally

${ }^{10}$ For detailed discussion on the impacts of the 1970s oil boom and its consequences, such as the intensified rent-secking activities new alliances between state bureaucrats, their families, and expanding corruption levels in Indonesia see Richard Robison, Indonesia: The Rise of Capital (Sydney: Allen and Unwin, 1980).

11 Sidney R. Jones, "It Can't Happen Here: a Post-Khomeini Look at Indonesian Islam," Asian Survey, 20 (3), 1980, pp. 311-323.

12 Yon Machmudi, Islamising Indonesia: The Rise of Jemaab Tarbiyab and the Prosperous Justice Parti (PKS) (Canberta: ANU University Ptess, 2008); Ken Miichi, 'Penetration of 'Moderate' Islamism in Contemporary Indonesia," in Kisaichi Masatoshi (ed.), Popular Movements and Democratization in the Islamic World (New York: Routledge, 2006), pp. 126-142.

${ }_{13}$ Abangan is Javanese Muslims who practice Islamic values while continuing to hold animistic values as central to their own well-being as : oposed to the more puritan Muslims, 
tribal communities, the New Order government promoted 'agamaisasi (religiosiation).' To this end, the government obliged its citizens to adhere one of five recognised religions; Islam, Catholicism, Christianity, Hindu and Buddha. ${ }^{14}$ The number of people embracing religion went steadily. It is almost impossible to find people without any one of recognised religions as their identity, including those who previously embraced any local religions were absorbed to these official religions. On the other hand, to secure its political power, the government obliged its citizens to keep the involvement of society in political affairs at bay. In so doing, the government introduced the 'depolitisation' by which Indonesians should vote for the government party, Golkar, in the elections and avoid any political activities deemed as contradicted to the government interests. In religious sphere, the government supports for 'cultural Islam.' This cultural Islam demands the non-political stances in the face of the government and supports the developmentalism project of the state. In addition, during $1970 \mathrm{~s}-1990 \mathrm{~s}$, the state had started to realise the importance of Islam as its popular supports for the government programs through establishing quasi-Muslim organisations. ${ }^{15}$ In 1975 , the government approved the establishment of the Council of Indonesian Ulama (Majelis Ulama Indonesia/MUI) which played major roles, through its fatwas, in defending the state's interests, ${ }^{16}$ whereas the foundation of the Indonesian Muslim

santri or "committed Muslims," see, Clifford Geertz, The Religion of Java (Glencoe, IL: Free Press, 1964), p. 5-7; Koentjaraningrat, Javanese Culture (Singapore: Oxford University Press, 1985), p. 316-323.

14 Deliar Noet, "Contemporaty Political Dimensions of Islam," in M.B. Hooker (ed.), Islam in South-East Asia (Leiden: Brill, 1988), p. 196; Donald K. Emmerson, Islam in Modem Indonesia: Political Impasse, Cultural Opportunity', in Philip H. Stoddard, etc. (eds.), Change and the Muslim World (Syracuse: Syracuse University Press, 1981), p. 165; John R. Bowen, Religions in Practice: An Approach to the Antbropology of Religion, 4th Edition, (Boston: Pearson Education, Inc., 2008), pp. 28-30.

15 Donald J. Porter, Managing Politics and Islam in Indonesia (London and New York: RoutledgeCurzon, 2002), chapter 5.

${ }^{16}$ Mohammad Atho Mudzhar, Fatwa-fatwa Majelis Ulama Indonesia: Sebuah Studi tentang Pemikiran Hukum Islam di Indonesia 1975-1988. Trans. Soedarso Soekamo Jakarta: INIS, 1993), for the attitudes of MUI in the reformation era, see Moch Nur Ichwan, "Ulama, State and Politics: Majelis Ulama Indonesia after Suharto," Islamic Law and Society, 45, 2005, pp. 45-72. 
Intellectuals' Association (Ikatan Cendekiawan Muslim Indonesia/ICMI) in 1990 signified the gaining economic and political influences of middle class Muslim in the national politics. ${ }^{17}$

The last decade of the New Order is of the paramount of the government's interest to draw Muslims' supports by making Islam as a popular basis of the stare's legitimacy. Not only did the government support the cultural expression -not to mention politically circumcised version- of Islam, but also use the radical groups as vehicles for its Islamic supports. This was hitherto with the growing endangering images of Christians and the danger of Jewish conspiracy in Indonesia. ${ }^{18}$ Unlike in the preceding period when the New Order government made 'a faithful alliance' with a number of Christian in the Indonesian military circles, the 1990s New Order political attitudes showed otherwise as it considered the previous ally. as a threat to the state power. The government further sided with some Islamic radical organisations, such as the Committee for Islamic Global Solidarity (Komite Indonesia untuk Solidaritas Dunia Islam/KISDI) and furthermore some high-ranks military officers supported the establishment of the Islamic Defenders Front (Front Pembela Islam/FPI) in 1998. Both organisations were the primary political fronts defending the New Order which was demanded to overthrown in 1998.

In addition to the foregoing political dimension of the rise of Islamic public and the rise of middle class Muslims, the development of media is probably the most significant element contributing to the creation of the Indonesian Islam public sphere. As Robinson notes on the importance of 'print Islam' as a vehicle for the dissemination of Islamic reformism ideas in the Muslim World, ${ }^{19}$ the intemet can be considered replacing the significant roles

17 Robert W. Hefner, Civil Islawr Muskums and democratization in Indonesia (Princeton: Princeton University Press, 2000), pp. 141-144.

${ }^{18} \mathrm{On}$ discussion on the imagined threat of Jewish conspiracy in Indonesia see Martin van Bruinessen, "Yahudi Sebagai Simbol dalam Wacana Islam Indonesia Masa Kini", Paper Presented at Institut Dialog Antar-Iman di Indonesia, Yogyzarta-Indonesia, 17 October 1993, available at http://wowletuu,gl/ martinganbruinessen/personal/publications/Bruinessen Yahudi seba 2ai simbolpdf accessed 10 August 2011.

19 Francis Robinson, "Technology and Religious Change: Islam and the Impact of Print," Modern Asian Studies, Vol 27, No. 1, 1993, pp. 229-251. 
that previously print media played leading to the modern Muslim world. ${ }^{20}$ Not only does the Intemet provide a more convenient, easier and cheaper ways to access information, it also offers 'an easy click' to fulfil their needs for information and religious guidance to find Islamic certainty in their religious life by googing fatwa, in addition to create public sphere more public. ${ }^{22}$

\section{Manifestations of Islam in the Public Sphere}

As the largest Muslim country, Indonesia, from the geographical point of views, is peripheral since located thousand kilometres away from the centre of Islam in the Middle East. In addition, the history of Islam in Indonesia also reveals that Islam has been well-flourished among people whose historical records demonstrate the previously dominated Hindu-Buddha influences, in addition to Christian and local religicus practices in the eastern part of the country. However, Islam in Indonesia has accelerated peculiar experiences as consequences of the global interaction among believers, with the Westem world as well as of its intemal dynamics. Of these experiences are diverse manifestations of Islam in the contemporary Indonesian public sphere. The varieties of contemporary Islamic expressions in Indonesia are subjects of the following discussion.

Since the reformation era in 1998, Indonesians bave publicly witnessed the birth of ideological manifestation of Islam, ranging from the political Islamist to the jihadist. However, both share similarities in the sense of Islamic objectives as Islam is perceived as an alternative to the established secular government and offers a model for mundane and practical political system aimed at creating the

20 For the significant roles of the Internet in shaping the Indonesia public sphere see Merlyna Lim, "From Real to Virtual (and Back again): Civil Society, Public Sphere, and the Internet in Indonesia" in Kong-Chong Ho, Randy Kluver, Kenneth C. C. Yang (eds.), Asia.com: Asia Encounters the Internet (New York: RoutledgeCurzon, 2003), pp. 113-128.

21 Nadirsyah Hosen, "Online Fatwa in Indonesia: From Shopping to Googling a Kiai," Greg Fealy,Sally White (eds.), Expressing Islam: Religious Life and Politics in Indomesia (Singapore: ISEAS Publishing, 2008), pp. 159-173.

22 Jon W. Anderson, "the Internet and Islam's New Intexpreters" in Dale F. Eickelman and Jon W. Anderson (eds.), New Media in the Muslim World: The Emerging of Public Spber (Bloomington and Indianapolis: Indiana University Press, 1999), pp. 45-60. 
truthful Islamic society respectively. The Islamist party, the Prosperous Justice Party (Partai Keadilan Sejabtera/PKS), ${ }^{23}$ represents the political Islamist model, whereas the more militant organisations, such as Hizbut Tabrir Indonesia/HTI, Majelis Mujabidin Indonesian/MMI and Jamaab Ansharut Taubid/JAT, demonstrate the more-radical expressions. Whereas the former model demonstrates the continuity of political ideas transferred from the Middle East with a loose interpretation in accordance with modern subjects and contexts through democracy and the implementation of shatiah bylaws, the latter tends to be adopting the imported ideas without any creative thinking (ijtihad) and takes more radical Islamic interpretations, believing that the social transformation of the society demands the continuous struggle against the enemies of Islam through jihad projects in the country. This latter then inspires the terrotist activities to overthrow the legitimate government and to attack the symbolic presences of the Westem interests in Indonesia. ${ }^{24}$

Opposed to the foregoing political manifestation, Indonesians also witness the rise of 'Islam Liberal' whose main proponents are intellectuals and Muslim scholars. ${ }^{25}$ The Islam liberal in Indonesia takes its roots from both modernist and traditionalist. ${ }^{26}$ Nur Cholis Madjid, one of leading intellectual from modernist side, gained full supports from the New Order with his 1970s slogan on Islam Yes, Islamic party No," whereas Abdurrahman Wahid, another figure of Islam liberal from traditionalist side, took critical attitude to the

${ }^{23}$ Established on 20 April 2002, the PKS, originally founded as the Partai Keadilan (PK) that failed to reach electoral threshold in the 1999 election, took its roots from the tarbiyab movement in the 1980s. In spite of claiming as an Islamic party, the PKS also claims as dakwa party. Currently, the PKS achieves remarkable voters as it is one of influential party in the government and the people council (Dewan Perwakilan Rakyat/DPR), see Yon Machmudi, Islamising Indonesia; Ali Said Damanik, Fenomena Partai Keadilan (akarta: Teraju, 2002); Masdar Hilmy, Islanism and Democracy in Indonesia: Piety and Pragmatism (Singapore: ISEAS Publishing, 2010)

24 Syaifudin Zuhri, "Transnationalising Jamaah Islamiyyah," Al-Jami'ah, Vol. 48, Number 1, 2010, pp. 45-80.

25 On the discussion of Islam Liberal see Charles Kurzman (ed.), Islam Liberat: a Source Book (Oxford: Oxford University Press, 1998)

${ }^{26}$ Greg Barton, "Neo-Modernism: a Vital Synthesis of Traditionalist and Modernist Islamic Thought in Indonesia," Studia Islanika, vol. 2, no. 3, 1995, pp. 1-75. 
government ${ }^{27}$ However, both are against the political manifestation of Islam in the matters of politics as they reject neither the formalisation of Islam through politics nor the implementation of shariah bylaws for the country. For the proponents of Islam Liberal, Islam is a religion, not a political ideology, and mundane matters, including in political affairs, belong the Muslims rights. Muslims have rights to interpret their religion in accordance with the Indonesian contexts. Unlike the political manifestation of Islam, the Islam liberal sought for democratisation as the best political model to bridge the interests of the state on the one hand and of the society on the other hand. Democracy is perceived as the best political system for the country as it prevents the extremes of authoritarianism rule and popular revolt respectively.

Apart from the foregoing two, there are also the growing diverse Islamic expressions within the societal level, ranging from Islamic spiritualism to stylish model for religiosity. One of important forms of these expressions is sufism. A number of spiritual trainings took a place in the marvellous five star hotels, fulfilling the growing demands for the spiritual progress, rather than material development, of the middle class and elites, whereas the more traditional sufism (tarekat) some are benefited the government patronage and other develops among rural communities. ${ }^{28}$ Sufism institutions and trainings are founded fulfilling the demands for the spiritual hunger of people who are not only rural, but also urban communities. Furthermore, this spiritual demand is not confined to the middle class, but also the lower-middle. A number of Islamic spiritual trainings with cheap price are founded, competing with the more expensive trainings offered for the middle and elites. In addition, television stations have broadcasted programs on spiritual techniques and the how-to-do shows in performing Islamic worships, such as Abu Sangkan's show on the practical benefits of performing prayers perfectly and how to achieve this perfection. It

27 Malcolm Cone, "Neo-Modern Islam in Suharto's Era," New Zealand Journal of Asiat Studies 4, 2 (December, 2002), pp. 52-67.

${ }^{28}$ Julia Day Howell, "Sufism and the Indonesian Islamic Revival," The Joumal of Asiat Studies 60, no. 3 (August 2001), pp. 701-729. 
is generally maintained that sufism serves as an alternative cure for diseases affected by modernism.

Another visible manifestation of Islam in societal dimension is the growing demands for Islamic life style. Islam is considered as one of determinative factors to the establishment of piety through visual appearances, such as through 'Baju Muslimah' for women Muslims and 'Baju Koko' for male Muslims that are deemed as signs for Islamic piety in the public sphere. ${ }^{29}$ The rising demand for visual piety further raises the needs to create Islamic fashion which integrates the fulfilment of Islamic values, covering aurat, and to be stylish altogether. Along with this demand, fashion designers begin to create Islamic fashion, whereas models, walking through the catwalk with jilbab, covering their aurat, and commercial advertisement offer the public with 'commodified Islamic fashion.' Various kinds of jilbab designed elegantly are available in commercial markets and undoubtedly disapprove the traditionalism image of the Islamic fashion, showing the inherent modern values of Islam. Furthermore, the trend for wearing jilbab among muslima is followed by many women politicians and celebrities wearing jilbab in their public appearances which subsequently expands the demands for being pious and stylish altogether.

Traditional Islamic health services (tibbun nabawi or the prophetic medical treatment) is another form of manifestations of Islam in the contemporary Indonesia. This medical treatment includes rukyat (recitation to get rid of evil from one's body), bekam (a vacuum cup to draw off unclean blood) and babbatus sauda (black caraway seed). Unlike the modern medical treatment which demands expensive cost and to some extent are inaccessible for the lower class Muslim, Islam medical treatment offers low-priced services and serves as an alternative medical treatment for Muslims to solve their health problems and to follow the prophet' tradition respectively. This traditional medical treatment is promoted through newspapers, magazines, television programmes and webportals, reaching the far audiences.

${ }^{29}$ Nancy J. Smith-Hefner, "Javanese Women and the Veil in Post-Soeharto Indonesia," The Journal of Asian Studies, 66 (2), 2007, pp. 389-420. 
In addition, it is important to note Indonesians have been offered by the aura of Islamic sanctity through films and publications. If the preceding period, book translations, mainly from Arabic, had been dominating the Islamic publication, the recent year publication underlines that Indonesian writers are taking roles in this wave. Habiburraham al-Shirazy's novels entitled "Ayat-Ayat Cinta", "Ketika Cinta Bertasbi,"31 -both were later filmed- for example, have gained a wide attention of the public and offered Islam as the solution for the contemporary social problems, mainly among youth Muslims. In addition to novels, the publication includes popular books, comics, and magazines. ${ }^{32}$ Besides highlighting the importance of Islam as an alternative way of life rather than consumerisms and hedonism that modernity offers, Islamic publication and film's provide a sphere where Islamic agenda, such as on gender, education, ethics, morality and else, are discoursed along with entertainment nuance in order to gain the public attention, mainly that of youth Muslims.

'Tele-Islamic preaching' is of significant forms of Islamic expressions in the contemporary Indonesia. ${ }^{33}$ This aired Islamic preaching program resembles that of Christian televangelism in A.merica. ${ }^{34}$ Many of the preachers are not ulama in traditional religious sense as they are educated in secular schools/universities and come from backgrounds in film, music and some ate newly converts. However, there is no doubt that they are very capable of

${ }^{30}$ Lukman Hakim, "Conservative Islam Tum or Popular Islam? an Analysis of the Film Ayat-ayat Cinta," Al-jamiab, Vol. 48 No. 1, 2010, pp. 101-128.

31 Ekky Imanjaya, "When Love Glorifies God" at http://www insideindonesia.org/edition-97/when-love-glorifies-god-09081229 (accessed 2 August 2011)

32 Najib Kailani, "Muslimising Indonesian Youths: The Tarbiyah Moral and Cuttural Movement in Contemporary Indonesia" in Remy Medinier (ed.), Islam and the 2009 Indonesian Elections, Political and Cultural Issues: The Case of the Prosperous Justice Party (PKS) (Bangkok: IRASEC, 2010), pp. 71-96.

33 Ahmad Muzakki, "Islam as a Symbolic Commodity: Transmitting and Consuming Islam through Public Sermons in Indonesia" in Pattana Kitiarsa (ed.), Religious Commodifications in Asia: Marketing Gods (Oxon; Routledge, 2008), pp. 205-219.

34 Julia Day Howell, "Modulations of Active Piety: Professors and Televangelists as Promoters of Indonesian Sufism" in Greg Fealy and Sally White (eds), Expressing Islam: Religious Life and Politics in Indonesia (Singapore, ISEAS Publishing, 2008), pp.40-62. 
communicating the Islamic lessons to the masses. This communication skill enables them to satisfy the needs for religious edification and entertainment simultaneously. ${ }^{35}$ Uje (Ustadz Jefri al Buchori), for example, gains his popularity as ustad gaul (friendly Islamic preacher) and regularly appears in television soap operas, in addition to Islamic preaching programs in some broadcasted programmes of television stations. As with $\mathrm{Uje}$, a famous Islamic preacher, Aa Gym (Ahdullah Gymnastiar), is not a ulama in traditional sense as he is not educated in Islamic educational institutions. As he resigned from his military position, he run his Islamic businesses under the Majamemen Qolbu (the Management of Heart) and launches his music CD "Jagalah Hati" (Maintain Your Heart). However, they share similarities in common leading their popularity as preachers; they are able to synergize preaching skills and entertainment altogether.

In addition, we should also pay our attention to the development of Islamic music (musik Islami) in Indonesia. The most remarkable elements of Islamic music in Indonesia is that it incorporates various music instruments, from local, such as gamelan to imported ones, and imbues Islamic massages to the lyrics, serving as a medium for dakwa activism. ${ }^{36}$ In addition, the contemporary Indonesia Islamic sphere demonstrates the composed Islamic songs compromise multitude influences and genres. Nashid (acapella) genre song is influenced by the Middle Eastern music, ${ }^{37}$ whereas the $R \& B$ and rock [slamic songs, such as Insomnia album of Gigi and Para Pencari-Mu of Ungu ind others are might be better perceived as under Western influences.

${ }^{35}$ Noorhaidi Hasan, "The Making of Public Islam: Piety, Agency, and Commodifications in the Landscape of the Indonesian Public Sphete," Contemporary Islam, 3, 2009, Pp. 229-250; ulian Millie, "Preachers, Politics and Piety: Dakwah Oratory in A Changing Indonesia" in Lsian Cuments: The Asian Studies Association of Austratia's e-bulletin, August 2009 at 1tpi//asaa.asn.au/publications/ac/asian-curnents-09-08.html. accessed 1 August 2011.

36 David Hamish and Anne Rasmussen, "Introduction: the World of Islam in the Music If Indonesia" in David Hamish and Anne Rasmussen (eds.), Divine Inspirations: Music and Islam I Indonesia (New York Oxford University Press, 2011).

37 For the discussion on nasbid in Southeast Asia Muslim see Bart Barendregt, "Cyber Jashid: Transnational Soundscapes in Muslim Southeast Asia" in T. Holden and T. Scrase sds.), Medi@asia: Communication, Culture, Context (London: Routledge, 2006), pp. 171-187. 
Islamic banking system is another significant manifestation for the presence of Islam in the Indonesian public. Since the establishment of the socalled 'Bank Shariah' in the 1990s, shariah based-compliances have successfully generated public interests, absorbed billion money of the customers and subsequently invited the common banks (if not to mention secular) to establish their own Bank Shariah. By 2010, the country had 11 units of Shariah General Banks (Bank Umum Syariah/BUS), 23 shariah business units (as part of conventional banks) and 146 units of Shariah People Credit Bank (Bank Perkreditan Rakyat Syariah/BPRS), with number of offices totalling 1,388 units. The growing number of units has been followed with strong annual growth of $35 \%$ in their assets--from $\mathrm{Rp} 26.7$ trillion in 2006 to $\mathrm{Rp} 86$ trillion in $2010 .^{38}$

\section{Epilogue}

The contemporary Indonesian experiences demonstrate the continuity and change in the creation of Indonesian Islamic sphere. The creation however takes us to the decades of the New Order government under Suharto, the rise of middle class Muslim in Indonesia since the 1980s, the influence of Iranian revolution in 1979 and the advancement of information technology. The New Order's attitudes towards Islam, mainly during 1990s, paved the ways of Islamisation in nationai politics, whereas the economic growth in 1980s significantly contributed to the rise of middle class Indonesian Muslims. In the global contexts, the successful Iranian revolution in 1979 inspired their Indonesian Muslim counterparts to take a firm stance in face of global capitalism and the state authoritarianism as young Muslim activists began to see Islam as an alternative to capitalism and western ideologies, including the Pancasila. Furthermore, since the introduction of the Internet, Indonesian have been provided with cheaper, more convenient and easier access to information, including fulfilling their anxiety for religious spiritual, entertainment, and market. All the foregoing aspects have contributed to the making of Islamic

${ }^{38}$ Direktorat Perbankan Syariah BI, Outlook Perbankan Syariab Indonesia 2011 Jakarta: Direktorat Perbankan Syariah, 2011); Arskal Salim, 'Epilogue: Shari'a in Indonesia's Current Transition: an Update," in Arskal Salim and Azyumardi Azra (eds.), Shari'a and Politics in Modem Indonesia (Singapore: ISEAS Publication, 2003) 
phere in Indonesia. The contemporary Islamic sphere in Indonesia is to nclude diverse manifestations of Islam in the public sphere, ranging from ipiritual, ideological, intellectual, health services, Islamic fashion, music, films, jublication to economic ones. These manifestations are consequences of the nteraction between agencies, progress, local and global elements which further renerate the creation of 'hybrid forms' of Islam.

\section{REFERENCES}

Anderson, Jon W. 1999. "the Internet and Islam's New Interpreters" in Dale F.

Eickelman and Jan W. Anderson (eds.), Nen Media in the Muslim World:

The Emerging of Public Spbere. Bloomington and Indianapolis: Indiana University Press.

Barendregt, Bart. 2006. "Cyber Nashid: Transnational Soundscapes in Muslim

Southeast Asia" in T. Holden and T. Scrase (eds.). Medi@asia: Communication, Culture, Context. London: Routledge.

Barton, Greg. 1995. "Neo-Modernism: a Vital Synthesis of Traditionalist and Modernist Islamic Thought in Indonesia," Studia Islamika, vol. 2 , no. 3.

Bowen, John R. 2008. Religions in Practice: An Approach to the Anthropology of Religion, 4th Edition, Boston: Pearson Education, Inc.

Bruinessen, Martin van. 1993. "Yahudi Sebagai Simbol dalam Wacana Islam Indonesia Masa Kini", Paper Presented at Institut Dialog Antar-Iman di Indonesia, Yogyakarta-Indonesia, 9 October 1993, available at http://www.let.uu.nl/ martin.vanbruinessen/personal/publications/Bru inessen_Yahudi_sebagai_simbol.pdf, accessed 10 August 2011.

Burke, Peter. 2005. History and Social Theory, $2^{\text {nd }}$ ed., Cambridge: Polity.

Craig Calhoun. 1993. "Introduction: Habermas and the Public Sphere," in Calhoun, Craig (ed.), Habermas and the Public Spbere (Studies in Contemporary German Social Thought), Cambridge: MIT Press.

Casanova, José. 1994. Public Religions in the Modem World, Chicago: University of Chicago Press. 
Cone, Malcolm. 2002. "Neo-Modern Islam in Suharto's Era," Neny Zealand

Joumal of Asian Studies 4, 2, December.

Damanik, Ali Said. 2002. Fenomena Partai Keadilan, Jakarta: Teraju.

Direktorat Perbankan Syariah BI. 2011. Outlook Perbankan Syariab Indonesia 2011, Jakarta: Direktorat Perbankan Syariah.

Eickelman, Dale F. and Armando Salvatore. 2007. "Public Islam as an Antidote to Violence?," in Esther E. Gottlieb (ed.), Identity Conflicts: Can Violence be Regulated?, New Jersey: Transaction Publishers.

Emmerson, Donald K. 1981. Tslam in Modern Indonesia: Political Impasse, Cultural Opportunity', in Philip H. Stoddard, etc. (eds.), Change and the Muslim World, Syracuse: Syracuse University Press.

Geertz, Clifford, The Religion of Java, Glencoe, IL: Free Press, 1964.

Habermas, Jürgen. 1989. The Structural Transformation of the Public Spbere (Studies in Contemporary German Social Thought) (trans. 'Thomas Burger), Cambridge: The MIT Press.

Hakim, Lukman. 2010. "Conservative Islam Turn or Popular Islam? an Analysis of the Film Ayat-ayat Cinta," Al-jamiah, Vol. 48 No. 1.

Harnish, David and Anne Rasmussen. 2011. "Introduction: the World of Islam in the Music of Indonesia" in David Harnish and Anne Rasmussen (eds.), Divine Inspirations: Music and Islam in Indonesia. New York: Oxford University Press.

Hasan, Noorhaidi. 2009. "The Making of Public Islam: Piety, Agency, and Commodifications on the Landscape of the Indonesian Public Sphere," Contemporary Islam, 3.

Hefner, Robert W. 2000. Civil Islam: Muslims and democratization in Indonesia, Princeton: Princeton University Press.

Hilmy, Masdar. 2010. Islamism and Democracy in Indonesia: Piety and Pragmatism, Singapore: ISEAS Publishing.

Hosen, Nadirsyah. 2008. "Online Fatwa in Indonesia: From Shopping to Googling a Kiai," Greg Fealy,Sally White (eds.), Expressing Islam: Religious Life and Politics in Indonesia, Singapore: ISEAS Publishing. 
Howell, Julia Day. 2008. "Modulations of Active Piety: Professors and Televangelists as Promoters of Indonesian Sufism" in Greg Fealy and Sally White (eds), Expressing Islam: Religious Life and Politics in Indonesia, Singapore, ISEAS Publishing.

Howell, Julia Day. 2001. "Sufism and the Indonesian Islamic Revival," The Joumal of Asian Studies 60, no. 3, August 2001.

Ichwan, Moch Nur. 2005. "Ulama, State and Politics: Majelis Ulama Indonesia after Suharto," Islamic Law and Society, 45.

Imanjaya, Ekky, "When Love Glorifies God" at http://www.insideindonesia.org/edition-97/when-love-glorifies-god09081229 (accessed 2 August 2011)

Jones, Sidney R. 1980. “It Can't Happen Here: a Post-Khomeini Look at Indonesian Islam," Asian Suniey, 20 (3).

Kailani, Najib. 2010. "Muslimising Indonesian Youths: The Tarbiyah Moral and Cultural Movement in Contemporary Indonesia" in Remy Medinier (ed.), Islam and the 2009 Indonesian Elections, Political and Cultural Issues: The Case of the Prosperous Justice Party (PKS), Bangkok: IRASEC.

Kurzman, Charles (ed.).-1998. Islam Liberal: a Source Book, Oxford: Oxford University Press.

Koentjaraningrat. 1985. Javanese Culture, Singapore: Oxford University Press.

Lim, Merlyna 2003. "From Real to Virtual (and Back again): Civil Society, Public Sphere, and the Internet in Indonesia" in Kong-Chong Ho, Randy Kluver, Kenneth C. C. Yang (eds.), Asia.com: Asia Encounters the Internet, New York: RoutledgeCurzon.

Machmudi, Yon. 2008. Islamising Indonesia: The Rise of Jemaab Tarbiyab and the Prosperous Justice Parti (PKS), Canberra: ANU University Press.

Miichi, Ken. 2006. 'Penetration of Moderate' Islamism in Contemporary Indonesia," in Kisaichi Masatoshi (ed.), Popular Movements and Democratization in the Islamic World, New York: Routledge.

Millie, Julian, "Preachers, Politics and Piety: Dakwah Oratory in A Changing Indonesia" in Asian Currents: The Asian Studies Association of Australia's e- 
470 Millab Vol. XI, No. 2, Februari 2012

bulletin, August 2009 at http://asaa.asn.au/publications/ac/asiancurrents-09-08.html, accessed 1 August 2011

Mudzhar, Mohammad Atho. 1993. Fatwa-fatwa Majelis Ulama Indonesia: Sebuab

Studi tentang Pemikiran Hukum Islam di Indonesia 1975-1988, Trans. Soedarso Soekarno, Jakarta: INIS.

Muzakki, Ahmad. 2008. "Islam as a Symbolic Commodity: Transmitting and Consuming Islam through Public Sermons in Indonesia" in Pattana Kitiarsa (ed.), Religious Commodifications in Asia: Marketing Gods, Oxon: Routledge.

Noer, Deliar. 1988. "Contemporary Political Dimensions of Islam," in M.B. Hooker (ed.), Islam in South-East Asia, Leiden: Brill.

Porter, Donald J. 2002. Managing Politics and Islam in Indonesia, London arid New York: RoutledgeCurzon.

Ricklefs, M.C. 2008. "Religion, Politics, and Social Dynamics in Java: Historical and Contemporary Rhymes", Greg Fealy, Sally White (eds.), Expressing Islam: Religious Life and Politics in Indonesia, Singapore: ISEAS Publishing.

Robinson, Francis. 1993. "Technology and Religious Change: Islam and the Impact of Print," Modem Asian Studies, Vol. 27, No. 1.

Robison, Richard. 1986. Indonesia: The Rise of Capital, Sydney: Allen and Unwin.

Salim, Arskal. 2008. "Epilogue: Shari'a in Indonesia's Curtent Transition: an Update," in Arskal Salim and Azyumardi Azra (eds.), Shari'a and Politics in Modern Indonesia, Singapore: ISEAS Publication.

Salvatore, Armando and Dale F. Eickelman. 2006. "Preface Public Islam and the Common Good," Armando Salvatore and Dale F. Eickelman (eds.), Islam and the Common Good, Leiden: Brill.

Schulze, Reinhard. 2000. A Modern History of the Islamic World, London: IB Tauris.

Schwatz, Adam, 2000. A Nation in Waiting. Indonesia's Search for Stability, Oxford: Westview Press.

Smith-Hefner, Nancy J. 2007. "Javanese Women and the Veil in Post-Soeharto Indonesia," The Joumal of Asian Studies, 66 (2). 
Wiktorowicz, Quintan. 2001. The Management of Islamic Activism, New York: State University of New York Press.

Zaman, Muhammad Qasim. 2002. The Ulama in Contemporary Islam: Custodian of Change, Princeton: Princeton University Press.

Zuhri, Syaifudin. 2010. "Transnationalising Jamaah Islamiyyah," Al-Jami'ab, Vol. 48, Number 1. 
472 Millab Vol. XI, No. 2, Februari 2012 